\title{
An Analysis and Evaluation of Philosophical Bases of School of Illumination in Terms of Problem of Evil
}

\author{
Maryam Solgi \\ PhD student, Department of Philosophy, Faculty of Islamic sciences and Theology \\ Allameh Tabataba'i University, Tehran, Iran; Email: solgi.atu@gmail.com

\section{Ghasem Pourhassan Darzi} \\ Associate Professor, Department of Philosophy, Faculty of Islamic sciences and \\ TheologyAllameh Tabataba'i University, Tehran, Iran \\ Amir Abolfazl Hekmat Arjmand \\ A Professor of University and Hawza, Motahari University, Tehran, Iran
}

Doi:10.5901/mjss.2016.v7n1s1p103

\begin{abstract}
The two main ways to study the problem of evil are as follows: a) studying it as the logical problem of evil or the problem of the compatibility or incompatibility the existence of the God and the existence of evil; and b) evidential problem of evil. Suhrawardi tried to address both of these ways. The most important philosophical bases of the problem of evil in view of Suhrawardi are the following five ones: a) refutation of the humanism; b) accepting evil as a non-being; c) accepting the doctrine of the higher seeking nothing from the lower; d) dividing the contingent things based on the system of good and evil; e) accepting the doctrine that evil is the precondition of existence of higher good. By accepting the said principles, Suhrawardi solved the problem either way. In the first place, he demonstrated that evil is not inconsistent with the God by demonstrating omniscience of the God, and in the second place, he demonstrated that the existence of evil in the world would thus not be inconsistent with the existence of the God.
\end{abstract}

Keywords: good, evil, illuminated, darkness, higher good, humanism

\section{Introduction}

Contemporary thinkers proposed two main readings of the problem of evil as follows:

1. The logical problem of evil (or question of consistence and inconsistence of God's existence and the evil.

2. Evidential problem of evil. All Muslim thinkers including Suhrawardi has adopted the second approach and tried to answer it in different ways. However, this doesn't mean rejection or failure to consider the first way. The author believes that the first way must be considered within the second way. Thus, most thinkers who provided a solution to the problem of evil have stated that existence of God and evil can be compatible. Solutions provided by Suhrawardi and other Muslim thinkers are mostly based on divine justice. However, of the two defenses of which one is based on higher good and another on free will, the first is preferred, and Suhrawardi based most of his discussions on the first defense.

The main challenge about problem of evil is resolved upon scrutiny on works of Surawardi about evil and his philosophical bases. Thus, one who is agreed with bases of School of Illumination as discussed later will not face the main challenge and associated question.

Suhrawardi, the inventor or his interpretation of life is the light of wisdom, all ranks and degrees are analyzed in terms of light and darkness as well. It can be said on the basis of philosophical, good and evil are the basic concepts of School of Illumination and evaluations are very important and necessary. Topics include discussion of good and evil "light and darkness" are proposed to be scattered among the works of Suhrawardi are observed. 


\section{Philosophical Bases of Suhrawardi with Regard to Problem of Evil}

Philosophical bases of Suhrawardi with regard to problem of evil briefly include:

a) Accepting principle that the human is not by definition the center of the creation and considering the things as being divided into good and evil. Accepting of this by the human ultimately results in partial evil turning into general good in the best system.

b) Accepting the principle that evil is requirement of existence of higher good. As a result of accepting this principle, not only existence of evil doesn't contradict the God being pure good, but also evil doesn't challenge the wisdom of the God.

c) Accepting evil as a non-being unreal thing that is not existential.

d) Rational limitation on dividing creatures based on system of good and evil, as a result of which the God is established as pure good and it is proven that small evil is not inconsistent with attribute of being pure good.

e) Accepting doctrine of the higher seeking nothing from the lower, which results in non-competency of the human to negate the absolute attributes of the God.

\subsection{Refutation of the theory of humanism and accepting the best system}

In all challenges regarding of evil, the human is axis of system of good and evil, that is, if something is good for the human and provide them with peace and wellbeing, it is deemed as good, and if something harms them, and disturbs their peace and wellbeing, it is evil. However, this is not a real and objective view of evil, but is based on partial subject human perspective, which denies the omniscient and omnipotent God upon recognition of evil. According to Suhrawardi, one who insists on exclusion of evil from the world and who believes existence of existence of purely good God is inconsistent with evil is misled by the belief that the world is created for the human only (Suhrawardi, 1996c: 60-61). If it is assumed that evil people are more than good people in the world then it is concluded that evil prevails over good, while Suhrawardi stresses that this is not true, and number of good people is more than bad ones (Suhrawardi, 1996c: 62; Suhrawardi, 1996a: 473).

\subsubsection{Analysis}

Based on opinion of Suhrawardi, it can be said that;

1- Viewing the issue from a human-centered perspective, problem of evil is considered as was discussed above, otherwise, it should be concluded that although the evil harms the man, the wellbeing and perfection may be dependent on such evil, and if the human could see the whole universe, they would not consider the evil people as evil, but would consider them as the good in the whole universe, in which the parts are connected in an intelligent system.

2- If there was no contradiction, the nature would not realize and survive, and this claim is experienced and understandable in the world based on what is seen in the nature and based on concept of the nature. With respect to the question "how evil is included in divine ordain", which is discussed under the same name in Islamic philosophic books, different answers have been provided, one of which is that contradiction, including one between good and evil, is one of the requirements of the nature and unavoidable.

3- What is called evil is evil relative to the thing against which it is measured but it is good relative to the whole universe. Suhrawardi believes that the existing system is the best system.

4- After having mentioned the two cases (c) and (d), Suhrawardi combines the dual responses and makes one secondary to another using the expression "therefore", because two answers are very close, because if contradiction is requirement of nature, what is called good or evil is one side, and it is neither good nor evil, and if nature didn't involve evil and didn't survive in its presence, it could be said that such system is the best natural system. That is, this system cannot be better. And because what is sought is existence of a nature with such good attribute and in favor of all people, then, there is no evil. However, there is some criticism:

First, according to above meaning, if there is no evil, then there is no good, good and evil are measured relative to particular people and cases, while there is no good and evil in the whole system where the partial considerations are excluded. Good and evil must contradict and replace permanently for the nature to be progress. However, what is against good and against the human? It should be said that none of this statements applies to the nature, but by taking the statement of problem to be true, this doesn't comply the divine ordain and justice and favor of the God. This is because it involves particular cases, for example, why 
one is affected with a condition which is deemed as evil, at the same time another person who is in no way better than the former is in the condition that is good for him. Then, what was said as answer is solution or modification of the problem.

Second, assuming the statement to be true, it can said "is a world not involving contradiction possible? Of course, existence of contradiction is established, but it is established that another world, no matter what it is called, is not possible. Then, that this system is the best is not absolutely established.

5- Suhrawardi said, "Some creatures may also be free from evil, for example, reasonable persons and the like, and some may have much good and little evil" (Suhrawardi, 1996a: 467).

This answer is new and he accept good and evil are true but good is more than evil on the whole, and even says every man receives more good than evil.

The result of calculation of sum plus sum may be accepted based on defective conjectural experience, however, the same is hardly acceptable for people. When people are involved, it is impossible to discern good and evil accurately enough because what is evil for one is good for another. One's view may even change and there is no fixed criterion to see what judgment is true. Besides, why the assumption of little evil and huge good should be accepted?

If the basis of such requirement is the nature, it relates to first answer, while if it is out of expedience and utilitarian rational thinking, then, philosophical question wouldn't be solved.

6- Since god has perfect attributes, he doesn't do injustice. World is based on justice and meritocracy, if evil is more than good, god should be unjust then.

7- Evil is relative and personal, and what is evil for one may be good for another, and everything is good when seen from view of the whole universe.

8- Existing system is the best, and better than it is impossible, and criticism about such statement of Suhrawardi was discussed earlier.

9- Current system is requirement of natures of objectives and requirements of necessity, and non-liable will is not involved in it.

10- On the whole and based on statistics, evil is less than good.

11- If there was no evil in world, this would constitute much good, which in turn constituted evil.

12- Ethically, wellbeing and number of good people is more than evil ones.

\subsection{Requirement of evil being good in a higher level}

This view has three premises: first: association of good and evil; second: the world is the best system; three: association of abandoning much good and much evil. The question here is why world was not designed so that there would be no murder, etc. and the life would have an essential value and beauty. Suhrawardi well answered this. In Alwah Imadi and Partonamah, he said, "If so, this world would be pure good, and so it would fall in first category and not the second. If it is said why such type in which there is no evil is created, the answer is such question is problematic, because it is like saying why water is not made of something other water and why fire is not something other than fire. And it is not right to compromise the general good for partial good" (Suhrawardi, 1996c, 165-166). Pain is evil in the first category. The opposite of it is pleasure and happiness that is good of first type. If it is asked what benefit of pain is, the answer is second type good include sympathy and courage, which is impossible without first type evil. Thus, first type good is much more important than first type evil. There is not important and high good of sympathy and courage unless there is first type evil.

Second involves sympathy with pain, courage in the face of danger and gradual diminishing of first type evil and increase of first type good (Plantinga, 1995). This answer as provided by monotheist philosophers or theologians justifies existence first type evil and also resolves the issue of incompatibility, as well as demonstrating that the world is the best one and no better world is possible logically. If we believe that evil is perquisite of higher good, the evil is an integral part of material world so that if the evil is excluded, the whole world is precluded. Thus, accepting this basis, existence of evil shall in no way contradict the existence and attributes of the God.

\subsubsection{Analysis}

Proof of best system is subject to philosophical bases, which claim is unfound; these bases include principle of principality of existence, principality of doubting existence, belief in real unity of world (multiplicity in unity and unity in multiplicity). If any of these is undermined, the claim may not be proven. Above principles are inconsistent with claims of 
some advocates of above theory. Therefore, philosophical schools supporting truth of nature or truth but denying unity of world and existence may not prove their claim. Thus it can be said belief in best system doesn't comply principle of truth of nature of Suhrawardi (Javadi Amoli, 1984). However, fair judgment of quantity of good and evil is possible with respect to realities of the human world because in real world the total evil is less than total good, because human natural finds out that in the whole human life, evils like permanent or temporary diseased people are less than healthy ones. As an advocate of the best system, Suhrawardi didn't deny the evil and their relative multiplicity. Although belief in best system is inconsistent with some of his philosophical bases, admitting existence of the evil, he considered them as precondition of higher goods, because although the evil is much relative to itself, it is very little compared to the entire good in the world; this is why Suhrawardi and other philosophers also refer to evil by "much" rather than "most".

Evil should not be measured from perspective of the human because the human is just one of many creatures. Such misunderstanding may be based on the fact that the human is said to be the best creature and the ultimate goal of creation in some hadiths. In response to this Suhrawardi said, "One for who the sky and the earth is created is another human whose existence is beyond the bodily world" (Suhrawardi, ibid). Although there must a distinction be made between real evil and failure of the human to reach their goals, and such failure of the human shouldn't be deemed as evil and it must be called much evil, belief of theologian in another world causes one not to able to render final judgment on smallness and largeness of evil and good. This is because the god believers consider death as start of new life, and material world is not end of human life. However, the question whether total good in material and other worlds is more than evil is left without final answer.

\subsection{Non-being of evil}

The third ground that causes the problem of evil not to be acceptable in Suhrawardi's philosophy of evil is non-being of evil. The third basis is "there is evil". Here, it is assumed evil is existential. Question is if evil is created or we consider it as evil due to lack of goodness and perfection of existence. Some believe those believe in non-being of evil shall not encounter the evidential problem of evil (Mackie, 1955).

Suhrawardi discussed good and evil issues given essence of god and believed his purely good essence doesn't give out evil, because evil is non-perfection and evil is non-existence and because non-being is non-being, it cannot be attributed to subject unless accidently (Heiderabadi, 2006). Suhrawardi believed may not be given out by god due to his being the illuminated of the illuminateds and lacking dark aspects, but also it may not be given out by abstract essences and the evil is attributed to things because of imperfect reason (Suhrawardi, 1996a). In demonstrating evil, philosophers have adopted three views: evidence, induction and deduction.

To prove his claim, Suhrawardi relied on deductive argument. The statement of the same is: if evil exists, evil become something other than evil, because the conclusion is false, then the premise is also false.

According to him, whatever exists is good, then if evil exists, evil become something other than evil. In his view, cruelty, poverty and darkness are necessary requirements of evidence, and like other requirements of nature, they may not be excluded from the nature (Suhrawardi, 1996a, p. 235, Suhrawardi, 1996c, p. 55).

\subsubsection{Analysis}

Suhrawardi believed in non-being of evil. He deemed darkness as main source of evil, thus taking distance from peripatetic scholars, but the outcome is same because he deemed darkness as result of movement and body of being and the peripatetic scholars deemed matter as cause of evil (Suhrawardi, 1996b, p. 235). In proof of non-being of evil, he invoked deductive argument, although this was first proposed by Qutb al-Din Shirazi, commentator of hikmat al-ishraq in Islamic philosophy, this argument can be said to be initiated by Suhrawardi, because the latter said so in hikmat al-ishraq.

Motahari analysis and evaluation begins with the question about the meaning of "evil is a non-being". Motahari said that none of these meanings were meant by philosophers. Those who say evil is non-being neither intend to deny evil nature of evil nor disclaim man and his role in completion of community (Motahari, 1997a). Then, what is the essence proposed by Farabi and Ibn Sina and Suhrawardi? The basis of the claim is that evil is privation and loss. The evil in the nature of the deficiencies and gaps. They are evil because either they are loss or they cause loss. Human role in the development of the world is to eradicate such defects (Motahari, 1997a). Problem of evil as a privation alone is not enough to solve the problem of theodicy, but it is the first step. The actual outcome of this discussion is that existence doesn't have two types (Motahari, 1997b; Motahari, 1997b).

Motahari believes not without nihilist approach, one cannot defend simplistic notion of good and evil. Therefore, only by adopting the definition of evil as imperfection, both duality is rejected and the inseparability of good and evil will 
be elaborated (Motahari, 1997a).

Allameh Jafari also challenged the theory that argues in response to Khayyam "as conflict is source of non-being and non-being is the source of evil, so God did not create conflict ", and added, "this is not a valid argument, because making any thing is making its essential parts as well. As a result, if conflict is deemed as the source of non-being, nonbeing considered a source of evil certainly results in evil attributable to God" (Jafari, 1986).

Augustine in the West is a supporter of the theory. Schleiermacher called by John Hick as the first critic of Augustine criticized this theory (Hick, 1993, p. 96). Hospers also considers this idea as a game with words (Hospers, n.d., p. 109). However, to maintain that evil is a non-being doesn't solve the philosophical problem of evil. But it must be said that such solution is used to resolve misunderstanding that evil exists and refuting the duality, and no more must be expected. Refuting forms of justifying justice and wisdom and divine grace must be done by other solutions.

\subsection{Classification of creatures}

In his different works, Suhrawardi divided realms of good and evil are divided into five parts. If one accepts this division as discussed in the following, one would deem small evil in the universe permissible, because based on rational reasons that Suhrawardi provides, within the limitations of reason, division of creatures based on good and evil, only three kinds of creatures are impossible. He divided creatures into five categories:

1. Creature that is not evil (omnibenevolent).

2. Creature that has much good and little evil.

3. Creature that is an absolute evil.

4. Creature that has little good and little good.

5. The creature in which good and evil are equal (Suhrawardi, 1996a; Suhrawardi, 1996b; Suhrawardi, 1996d).

In Talwihat, case three, Suhrawardi provided a more detail description of five divisions compared with his other works. There, both the five divisions and arguments in support and against the categories are found (Suhrawardi, 1996a, p. 78). However, the division of Suhrawardi comprises all creatures rather than contingent one, therefore, God falls in the first supplement. But with respect to the subject of the division, the contingent ones are presented here. In Hikmat alIshraq, he has similar but shorter statements compared with Talwihat (Suhrawardi, 1996a, Pp. 558-559). He deemed the first two types as permissible and three last as impossible. According to him, based on the rule of possibility of the best, it is impossible that the first kind, a creature that is not evil, realize, because when we see the non-best creature, the best creature has already realized in the world before the former, and because much evil is realizable in the world and abandoning much good for little evil is much evil, it is not possible for second type to exist as well. According to him, if one asks why God created no second type without evil, a corrupt questions has been asked, because it is impossible that God make something so that it is other than itself, for example, fire being something other fire, that is, it is burns but does not burn clothing. Moreover, if the little evil scarce is not deemed as being of this type, no other type would be created (Suhrawardi, 1996a, p. 467; Suhrawardi, 1996c, Pp. 61, 65). That is, if the world was just pure good, that would require that either the universe was not created, in which case grace would remain only within the abstract creatures, or the universe and ecstatic nature would not be the nature, in which case the object must not be itself, or ecstatic nature would lack essential means, in which case necessary requirements would be excluded from essence.

While Suhrawardi noted under the first type was only the Nur al-Anwar, Al-Farabi and Ibn Sina and Mulla Sadra and late Sabzevari, the abstract creatures are also pure good (because they don't move, and therefore they don't have evil and lack). Suhrawardi deemed evil to ensue from the movement and limb, which are formed in the very illuminated. Thus, according to him, the sole instance of pure good is the Nur al-Anwar.

To philosophers, the material world is the second type in which evil is small and good is much, including humans and animals and objects, and Suhrawardi presented every three examples, that is, the fire, animal and human, in Talwihat. But whether for Suhrawardi example of the second type is only the material world or all worlds after Illuminated Illuminateds is subject to further research. Given his stress on the first kind, all worlds must be in the second kind, while Suhrawardi refer only to the material world in the examples and deems reason as falling in the first kind.

The third type is balance of good and evil. Much evil and little good is fourth type and pure evil is the fifth type. In Talwihat and Hikmat al-Ishraq, Suhrawardi refers to the invalidity of the other three types that is out of scope of this paper. Islamic scholars have discussed division of good and evil into five divisions and they argued for second kind based on creation in which all creatures are equal, and for the three other types, argued based on similarity, according to which because god is wise, he doesn't make the predominantly evil superior over the predominantly good, and because god doesn't act exorbitantly, it is impossible that he create something in which good and equal are equal for the sake of the evil part. And finally creation of pure evil is essentially precluded because no pure evil is possible to realize, because 
existence of nothing requires its non-being (Javadi Amoli, 1984, p. 273).

\subsubsection{Analysis and Evaluation}

Aristotelian division is thus at the root of Suhrawardi's divisionism theory that is a response to nihilistic theory of evil of Plato. Allamah Tabatabai also noted in the footnote of Asfar the theory of divisionism to be attributed to Plato (Mulla Sadra Shirazi, 1991). The essential question here is how and why Suhrawardi is platonic in defining and explaining the nature of evil while on approach to the division of evil he is Aristotlean, while nihilistic theory of evil is attributed to Plato and the divisionism theory of the existence of evil is attributed to Aristotle. However, is the difference between master and pupil in terms of the problem of evil is so profound that Plato believed in nonbeing of evil, while Aristotle seemed to believe in the existence of evil?

Like other philosophers, when Suhrawardi was addressing the nature of good and evil, he was a Platonist thinks, but immediately turns to Aristotle's views on its five divisions. Didn't Suhrawardi and other scholars find any inconsistence between views of Plato and Aristotle on the problem of evil or they adopted a selective approach? Of various interpretations that can answer the above question the division of evil by Suhrawardi is chosen and used to explain the problem. Suhrawardi certainly defined evil as nonexistent or nonbeing, but he distinguished between essential evil and accidental evil, which is Platonic understanding of the evil. Suhrawardi denies the existence of any essential evil, as in Partonamah, he refuted pure evil, and added pure evil is impossible because it is impossible to realize, arguing that existence of nothing can require its nonbeing (Suhrawardi, 1996c, Pp. 60-66) On the other hand, Suhrawardi accepts that the existence of evil is relative.

Suhrawardi said that there is much benefit in creation of fire, but it is deemed as evil when it comes to its touching clothing or house in which case it causes fire, or existence of animal is itself good but it may cause harm and evil accidently such as the horn of cow tearing the abdomen of the human or lion or tiger attacking the human, and such evil is not absolute but relative (Suhrawardi, 1996a, p. 78).

Motahari, being affected by this view of Suhrawardi and that of other Islamic philosophers, stated in the book of Divine Justice that "evil is relative", he says it should be asked is such evil is a relative or real attribute. Evils comes in two types: the evil that itself is a nonbeing and evil that is existential, that is, it is evil because it is the source of a series of negative events. The first type evil include ignorance and powerlessness and poverty; these are real but negative attributes. And second type include those that are source of negative things such as floods, earthquakes and disease; these are relative. (Motahari, 1997a, Pp. 131-132).

In division of attributes of the objects, Suhrawardi considered two types: essential or real and relative or accidental. That is, everything has an in itself existence, such life, fire, animal and human, and also for itself existence. Objects that exist in themselves and in essence are real and considered as good for this reason, but in relation to other objects, they can be called evil for some reasons. What is true and the essence of things is good, but additional things are relative and according to Suhrawardi are subjective and conventional and so, they are not real, and do not really exist in the universe, and for this reason the evil is not created in itself and in essence and its being creature and effect of other thing is even accidental (Suhrawardi, 1996a). The result of this statement of Suhrawardi is that the evil is nonbeing or conventional and relative. In the seventh volume of Asfar, Mulla Sadra accepted the division of Suhrawardi (Mulla Sadra Shirazi, 1989). Next, it should be noted that if there was a justification found for the realization of evil and it could be shown to be wise and logical, such concepts as much and less and equality will become meaningless as regards it. In other words, the good and the evil exist independently of each other and in the divine system, each has its own end and goal. Considering that the majority of Islamic philosophers deem the subjects of the five possible types of good and evil as worlds and contingent beings, here the weakness of claim of incompatibility of the equal evil and even much evil with wisdom and grace of God appears according to theologians.

Another point to note is that how could one prove that good is more than evil, because all humans has a limited length of life and can only judge during the limited length of their own life, while judgment about the amount of good and evil in the whole world is beyond ability of the human.

\subsection{Accepting doctrine of the higher seeking nothing from the lower}

By accepting this doctrine, one cannot say god doesn't have attributes omniscience and pure goodness, because of evil. This means the higher doesn't seek anything from the lower, because the higher has all good attributes of the lower. Therefore, the higher has no intention out of his essence. As for the God, that the God seeks anything is inconsistent with his superiority (Heidarabadi, 2006, p. 262). According to Suhrawardi in Hayakil al-Nur, question evil and good is raised by 
one who thinks the higher seek anything from the lower, such question is completely false, and opinion that is based on this dark world is false. Using this doctrine of Suhrawardi (Suhrawardi, 1996c, Pp. 101-102), statements on evil can be juxtaposed with new statements and change the conclusion in favor of god believers:

1. God is omnipotent; 2- God is pure good; 3. God is omniscience; 4. Knowledge of creatures is limited; 5. There exists evil.

And logical challenge theories are added to it:

6. If God is omniscient and pure good, he knows how the best good realizes in the world.

7. If God is omnipotent, he can realize the best system in the world.

8. Creatures' knowledge is limited, and the higher seeks nothing from something other than himself, then, the creatures may not get comprehensive knowledge of the higher essence.

\subsubsection{Analysis and evaluation}

That evil is found in the world doesn't overshadow the fact that god is pure good and omniscient. It is finally concluded that if necessary existence is fully needless, his act has not ultimate reason and expedient justification, because his essence is so that he does the things in the most complete way and his act is not out of expedience, because it seems that failure of advocates of problem of evil to consider this issue has caused them to falsely believe that because there is no convincing explanation for evil, omniscience and absolute goodness of the god can be questioned and then existence of him can be questioned and finally negated.

\section{Conclusion}

Given what was said about the philosophical basis of evil from view of Suhrawardi, the propositions substantiating the problem of evil can be analyzed and conclusions against the conclusions and opinions of the advocates of evil-based challenges can be obtained, although some criticisms can be raised against such bases, which were discussed earlier, the propositions substantiating evil include:

1. The God is the absolute good. Suhrawardi fully accepts this proposition and his analysis and evaluation of this proposition is that the existence concurs with the good and because God is perfect and pure existence, so the God is absolute and pure good. In other words, evil is possible where a thing is limited or non-existent, and because God is absolute existence, then the God is absolute good and favors every creature, and gives good, form, etc., and gives them all attributes;

2. There is such a thing as evil. Suhrawardi didn't accept this proposition in a way that the advocates of problem of evil did, and believed that evil was non-being. Evil doesn't have an essence, but evil is absence of essence or the non-perfection of the essence. In other words, what exists is good as long as nothing of it is required to be negated.

3. Thus, based on these three propositions of philosophy of Suhrawardi, the claim that the three substantiating propositions are contradictory was refuted. What was discussed in this chapter as philosophical bases of Suhrawardi largely ruled out challenges of the opponents. These bases are adduced such as refutation of humanism theory, according to which the human is considered incompetent to attribute evil to external events, or the doctrine of division of contingent beings in terms of good and evil, according to which existence of small evil in the world causes no challenge and even it is necessary, and its absence would be inconsistent with the wisdom of the God.

4. Scrutiny on these doctrines, or in better worlds, viewing the world from this perspective precludes some challenges raised by the advocates of problem of evil.

\section{References}

Plantinga, A. (1995). Philosophical theology. Edd. Soltani, E.; Naraghi, A.; Tehran: Serat cultural institute.

Suhrawardi, S. (1996a). A collection of writings Sheikh Ishraq. Vol. I. Tehran: Institute for Cultural Research and Studies. Suhrawardi, S. (1996b). A collection of writings Sheikh Ishraq. Vol. II. Tehran: Institute for Cultural Research and Studies. Suhrawardi, S. (1996c). A collection of writings Sheikh Ishraq. Vol. III. Tehran: Institute for Cultural Research and Studies. Suhrawardi, S. (1996d). A collection of writings Sheikh Ishraq. Vol. IV. Tehran: Institute for Cultural Research and Studies. Shahrazuri, S. (2001). Sharh Hikmat al-Ishraq. Tehran: Institute for Humanities and Cultural Studies Mulla Sadra Shirazi, S. (1989). Al-Hikmah al-Muta'aliyah. Beirut: Dar al-Ihya' al-turath Arabi. 
Mulla Sadra Shirazi, S. (1991). SharhUsul al-Kafi. Tehran, Institute for Cultural Research and Studies Heiderabadi, A. (2006). Nahayah al-Zuhur (A commentary on Suhrawardi's Hayakil al-Nur). Tehran: University of Tehran Press. Javadi Amoli, A. (1984). The Origin and the Resurrection. Qom: Isra' Press.

Jafari, M. (1986). Character analysis and evaluation of Khayyam. Tehran: Keyahan Press.

Motahari, M. (1997a). Divine justice. Tehran: Sadra Press.

Motahari, M. (1997b). Collected Works. Tehran: Sadra Press.

Hick, J. (1993). Philosophy of Religion. Tehran: al-Hoda International Publications.

Mackie, J. (1955). Evil and Omnipotence. Mind 64. 